Dossiê: Teorias de linguagem e Estudos de Religião - Artigo Original ๑요

\title{
O pensamento ficcional e seus desdobramentos na formulação dos discursos teológicos
}

\author{
Fictional thinking and its developments in the formulation of theological \\ speeches
}

\author{
Abdruschin Schaeffer Rocha* \\ Alessandro Rodrigues Rocha**
}

\begin{abstract}
Resumo
O presente artigo se propõe discutir a relação entre realidade e ficcionalidade e suas implicações para a formulação de discursos teológicos. Parte do pressuposto de que, em geral, o ficcional é visto com suspeita pela religião e Teologia cristã, na medida em que se parte de uma concepção equivocada de realidade, razão pela qual as relações entre Teologia e ficcionalidade ainda são relativamente inexploradas. Ampara-se nas discussões que deram origem à tradição da estética da recepção, sobretudo em sua vertente ficcional, tal como proposta por Wolfgang Iser, e analisa a ficcionalidade na relação com o discurso racionalista e o pensamento dogmático. Finalmente, a partir das contribuições de Joseph Moingt e George Lindbeck, propõe dois aportes teológicos com vistas à recuperação do pensamento ficcional como alternativa ao dogmático/conceitual. Moingt nos auxilia a compreender Deus enquanto um ser-para-nós. Lindbeck, através de sua teoria cultural-linguística, nos ajuda a discutir sobre a linguagem e o lugar que esta ocupa na formulação e comunicação de conteúdos teológicos.
\end{abstract}

Palavras-chaves: ficcionalidade; realidade; discurso teológico; estética da recepção.

\begin{abstract}
This article aims to discuss the relationship between reality and fiction and its implications for the formulation of theological discourses. It is based on the assumption that, in general, the fictional is viewed with suspicion by religion and Christian Theology, insofar as it starts from a mistaken conception of reality, which is why relations between Theology and fictionality are still relatively unexplored. It is based on the discussions that originated the tradition of reception aesthetics, especially in its fictional aspect, as proposed by Wolfgang Iser, and analyzes the fictionality in its relation to rationalist discourse and dogmatic thinking. Finally, based on the contributions of Joseph Moingt and George Lindbeck, it proposes two theological contributions with the intention of recovering of the fictional thought as an alternative to the dogmatic/conceptual. Moingt helps us to understand God as a being-for-us. Lindbeck, through his cultural-linguistic theory, helps us to discuss the language and the place it occupies in the formulation and communication of theological contents.
\end{abstract}

Keywords: fictionality; reality; theological discourses; reception aesthetics.

\footnotetext{
Artigo submetido em 15 de outubro de 2018 e aprovado em 17 de dezembro de 2018.

* Doutor em Teologia pela PUC-RIO. Professor do Programa de Pós-Graduação (Mestrado Profissional) em Ciências das Religiões da Faculdade Unida de Vitória (Vitória/ES). País de origem: Brasil. E-mail: abdrus@gmail.com

** Doutor em Teologia pela PUC-Rio. Professor do Programa de Pós-Graduação (Mestrado Profissional) em Ciências das Religiões da Faculdade Unida de Vitória (Vitória/ES). País de Origem: Brasil. E-mail: alessandro@faculdadeunida.com.br
} 


\section{Introdução}

O presente artigo propõe uma discussão no campo da epistemologia teológica acerca de desafios que a formulação do discurso teológico enfrenta frequentemente, bem como de uma possibilidade de avanço considerando a mesma tarefa. Busca no campo da ficção o aporte capaz de assumir a dimensão linguística na construção das realidades. Nesse sentido, o que se propõe é um caminho para a teologia no qual a linguagem ficcional seja privilegiada em face às maneiras de dizer baseadas na estreiteza do dizer conceitual.

Para realizar tal tarefa percorreremos o seguinte caminho: em primeiro lugar, diante da problemática resultante da relação entre realidade e ficcionalidade, discutiremos a dimensão ficcional da realidade e a natureza da ficção como forma de dizer a realidade. Em seguida, avançaremos na proposição de que, sem o aporte da ficção no dizer teológico, corre-se o risco de que a teologia crie uma espécie de castelo de certezas, sendo a metáfora, portanto, o recurso adequado para a superação da doutrina como única forma de expressão da fé. Por fim, apresentaremos dois aportes teológicos para a recuperação do pensamento ficcional como alternativa ao dogmático/conceitual: consideraremos as contribuições de Joseph Moingt e George Lindbeck.

Os dois autores - cada um à sua maneira - são sugeridos como exemplos de abordagens possíveis a partir de uma crítica à linguagem essencialista, capaz de suscitar formulações não metafísicas. De Moingt, tomaremos a categoria "Deuspara-nós” e de Lindbeck a proposição cultural-linguística. Nesse sentido, o artigo pretende levantar questões importantes a partir do esgotamento da linguagem teológica dogmático-conceitual e refletir sobre alternativas capazes de abrir novas sendas para a formulação do dizer teológico. 


\section{Ficção da realidade e realidade da ficção}

Embora os estudos sobre ficcionalidade já estejam circulando há algum tempo, o que também inclui as posteriores críticas que já foram feitas por teóricos que caminharam por essa senda, trata-se de um tema ainda estranho à Teologia e pouco explorado nas ciências da religião. E, vale ressaltar, embora a Teologia construa o seu saber de modo interdisciplinar, a julgar por suas melhores versões, parece ser uma tendência certa lentidão em acompanhar o que se passa no mundo das ciências, não só as chamadas ciências duras, mas, também, as ciências humanas. O campo de pesquisa que trabalha o tema religião e ficcionalidade é ainda relativamente incipiente e os possíveis pontos de encontro ainda inexplorados. ${ }^{1}$ Por essas e outras razões, o ficcional, em geral, é visto sob suspeita, sobretudo quando consideramos o ambiente da religião e da Teologia cristã. Há inúmeras razões para isso. Vejamos algumas:

Em primeiro lugar, é preciso considerar o contexto cultural mais amplo: a Modernidade e o Protestantismo tornaram-se forças reacionárias, catedrais secularizadas que ainda destoam dos traços da arquitetura contemporânea. Tal dimensão reacionária se mostra exatamente naquilo que tornou, em algum momento, esses movimentos expressões progressistas. A fixação no método (científico/confessional) como caminho capaz de afirmar a potência do sujeito frente à passividade do objeto, acabou por produzir um mundo estreito, monocromático e impossível de fruição. Embora a Modernidade tenha se afastado significativamente das cosmovisões anteriores, ainda assim não conseguiu fugir de sua matriz fundacional, afinal, a força do sujeito moderno se estabelece sobre os pilares da autonomia, da liberdade e da racionalidade (HABERMAS, 1989). Principalmente esta última serviu de parâmetro, não só para a construção dos saberes científicos, mas, também, para a construção de caminhos de compreensão do texto bíblico.

\footnotetext{
${ }^{1}$ Segundo Paulo Nogueira, um dos teóricos que têm se debruçado sobre o tema, esse campo - inexplorado, sobretudo no Brasil apenas começa a ser mapeado (NOGUEIRA, 2015, p. 121).
} 
O cogito cartesiano, a abordagem histórico-gramatical da primeira geração do Protestantismo, a crítica da razão kantiana, o método dedutivo aplicado à formulação dos manuais de teologia e a inerrante pesquisa histórico-crítica, acabaram por reduzir a complexidade das tramas humanas que compuseram as diversas narrativas sobre a realidade. $\mathrm{O}$ enciclopedismo, por exemplo - enquanto movimento filosófico-cultural francês resultante do Iluminismo - , ao tentar enclausurar no conceito a indomável condição humana, reduziu ao logos a multidão de dimensões constituintes da vida do humano no mundo.

$\mathrm{Na}$ verdade, em certo sentido, a Modernidade pode ser vista como uma cultura da exposição, do desvelamento do mundo, cultura essa ressentida de um tempo em que o abscôndito supostamente era obstáculo ao conhecimento irrestrito do mundo. Nessa cultura refratária ao elusivo, a "conquista" parece ser fruto de uma atitude "desnudadora" que assume contornos epistemológicos. A Modernidade, portanto, desde que se estabelece como o horizonte próprio da quebra de limites e da consequente manifestação do que antes se encontrava oculto, coloca-se também como cultura avessa a qualquer noção de "mistério". “Trazer todos os segredos à baila”, portanto, é a vocação mais forte dessa cultura a que chamamos moderna. ${ }^{2}$ Além disso, é, sem dúvida, uma cultura que celebra a ousadia humana em servir-se do próprio entendimento (sapere aude), para se utilizar aqui de uma máxima do Iluminismo, popularizada por Kant (KANT, 2004, p. 11). Nesse sentido, impõe-se como uma busca sem limites de um conhecimento que já não reconhece mais restrições aos esforços humanos de "conquista". Mas, curiosamente, embora a Modernidade celebre o fim dos limites ao conhecimento humano, reforça esses mesmos limites ao vinculá-los e reduzi-los à razão conceitual. Uma expressão clara desse trato com o conhecimento é o advento da epistemologia como teoria do conhecimento.

\footnotetext{
${ }^{2}$ A expressão "saber é poder", recorrente nas obras de Francis Bacon, é um exemplo típico dessa tendência moderna de trazer tudo à luz da razão. Contra Aristóteles, Bacon se referirá aos equívocos de toda filosofia interpretada como contemplação. Para ele, todas as razões que Aristóteles apresenta em defesa da vida contemplativa "dizem respeito ao bem privado, ao prazer e à dignidade do indivíduo. Sob tal aspecto, não há dúvida que a vida contemplativa leva à palma [...] Mas os homens devem saber que neste teatro da vida humana apenas Deus e os anjos podem ser expectadores" (BACON, 1999, p. 11). E é nesse sentido que Bacon advoga a ideia de que o ser humano deve ser intérprete da natureza, pois, essa atividade hermenêutica possibilita colocar a natureza a serviço da força desbravadora do sujeito moderno.
} 
Uma segunda razão para essa suspeita da religião e da Teologia cristã com relação ao pensamento ficcional é a maneira como a relação entre realidade e ficção normalmente é pensada no contexto do senso comum. Em geral, assume-se que a ficção não apenas se distingue, mas se opõe à realidade. Ou seja, a realidade deriva daquilo que se pode ver, tocar, verificar. Entretanto, essa perspectiva ignora que o conceito de realidade também se define historicamente, também é refém das distintas perspectivas que se constroem contextualmente. Quanto a isso, assim se expressa Nogueira:

[...] diante dos avanços da física quântica, das teorias cognitivas e das neurociências, esse tipo de definição só pode ser uma caricatura do que possa vir a ser a "realidade". Considerar o mundo real como equivalente ao visível, material e verificável é resultado de uma construção histórica, que por sua vez vulgariza modelos epistemológicos datados. É diante desse tipo de visão de mundo e do que é real que se define o que é ficção. (NOGUEIRA, 2015, p. 125).

Portanto, na perspectiva do senso comum, a ficção transmite a ideia de algo que não existe, algo inventado, uma mentira ou, no melhor das hipóteses, um gênero literário. Mas, o que se deve pontuar é que esse entendimento a respeito da ficção deriva do modo como o senso comum, na verdade, compreende a realidade: como estado de coisas que independe de sujeitos localizados e não como um fluxo amorfo e caótico de eventos que necessita de organizações subjetivas historicamente datadas.

Mas, esse equívoco que acaba por gerar suspeitas não está presente apenas no senso comum. Também no universo acadêmico é possível verificar certa confusão em torno do ficcional, tanto no que respeita ao modo como construímos o mundo, como, também, ao modo como construímos a ficcionalidade literária. 3 Não é preciso muito esforço para se detectar, em muitas abordagens acadêmicas, a matriz metafísica que perpassa as distintas construções de mundo. Há uma tendência racionalista, altamente celebradora de conhecimentos que se produzem a

\footnotetext{
${ }^{3}$ Paulo Nogueira, ao retomar os estudos de Aleida Assmann, marca a distinção entre esses modelos de realidade que são historicamente datados - ou seja, embora sejam ordenados por nós, são tomados por realidade - e uma segunda modelização do mundo através do exercício da ficção literária. Enquanto na primeira modelização cria-se uma realidade verbal, tomada como realidade pelo senso comum, na segunda, não há uma relação direta com o real, mas, com a realidade verbal do primeiro nível. A ficção literária, nesse sentido, embora não seja a realidade, fornece um modelo histórico de realidade, tornando-a compreensível, ao modo de uma perspectiva do tipo "como se" (ASSMANN, 1980 apud NOGUEIRA, 2015, p. 124-125).
} 
partir de estruturas conceituais, que delineou boa parte de nossa construção ocidental de mundo, construção essa que até poderia ser vista como uma "metáfora forte" possível, mas que, infelizmente, traduz-se como estado de coisas, como realidade bruta e referencial (ROCHA, 2010, p. 251).

Dessa fixação na estrutura conceitual do conhecimento - que também estabelece um novo estatuto para a verdade - nasceu uma espécie de saber tácito, como muito bem identificou Wolfgang Iser, que sugere que se problematize a contradição entre ficção e realidade. A primeira de ordem menor, própria do entretenimento e da distração (lugar que passou a ocupar a literatura) e, a segunda, do domínio da verdade (lugar da crítica e do nomeado saber científico). Nesse sentido, uns se dedicam à fruição, outros à cognição. A partir dessa distinção rígida, supostamente não caberia cognição na fruição, nem fruição na cognição. Ao problematizar esse saber tácito, Iser afirma:

É hoje amplamente aceito que os textos literários são de natureza ficcional. Por esta classificação, distinguem-se dos textos que, não possuindo tal característica, relacionam-se com o pólo oposto à ficção, ou seja, com a realidade. A oposição entre realidade e ficção faz parte do repertório elementar de nosso "saber tácito", e com esta expressão, cunhada pela sociologia do conhecimento, faz referência ao repertório de certezas que se mostra tão seguro a ponto de parecer evidente por si mesmo. É entretanto discutível se esta distinção, por certo prática, entre textos ficcionais e não ficcionais, pode ser estabelecida a partir da oposição usual. Os textos "ficcionados" serão de fato tão ficcionais e os que assim não se dizem serão de fato isentos de ficções? (ISER, 1996, p. 13).

Se levarmos a sério a perspectiva iseriana, a oposição marcante entre realidade e ficção acaba sendo anacrônica, na medida em que se baseia num conceito moderno e discutível de realidade, que se estabeleceu como saber tácito. $\mathrm{Na}$ verdade, a distinção cirúrgica entre ficção e realidade só é possível num ambiente artificial assepticamente construído para que a realidade com sua dinâmica e contradições fique do lado de fora. Para além de tal ambiente de ilusão, toda narrativa é ficcionalizada. Toda trama histórica que um texto literário oferece consiste num jogo entre sujeitos, numa disputa de memórias, numa espiralada cadeia de recepções. $O$ perito que lida com tais textualidades não pode desprezar os fios ficcionais dos discursos como sendo obstáculos a serem superados rumo ao 
encontro de uma intenção autoral escondida atrás de dissimulações. Não há um autor isolado a ser encontrado numa cruzada arqueológica. Há comunidades de leitores autorais que se apresentam como sujeitos de uma história de efeitos que se agiganta à medida que os textos vão sendo acessados.

Hans Robert Jauss, em sua obra A história da literatura como provocação à teoria literária, funda a crítica ao ensino de literatura que acabava por ser reduzida à história da literatura - numa perspectiva historicista que se fixava no mundo por trás do texto -, apontando para o devido lugar do leitor no processo de construção permanente de sentido e da fruição estética como experiência a ser considerada permanentemente como centro das atividades profissionais em face da pesquisa e ensino das narrativas literárias. Nas palavras de Jauss:

Uma renovação da história da literatura demanda que se ponham abaixo os preconceitos do objetivismo histórico e que se fundamentem as estéticas tradicionais da produção e da representação numa estética da recepção e do efeito. A historicidade da literatura não repousa numa conexão de "fatos literários" estabelecida post festum, mas no experienciar dinâmico da obra literária por parte de seus leitores. Essa mesma relação dialógica constitui o pressuposto também da história da literatura. E isso porque, antes de ser capaz de compreender e classificar uma obra, o historiador da literatura tem sempre de novamente fazer-se, ele próprio, leitor. Em outras palavras: ele tem de ser capaz de fundamentar seu próprio juízo tomando em conta sua posição presente na série histórica dos leitores. (JAUSS, 1994, p. 24).

Ao ressaltar a condição de leitor numa cadeia de outros tantos leitores que o pesquisador invariavelmente ocupa, Jauss pode ajudar na percepção de que toda pesquisa tem elementos de subjetividade e que tal subjetividade é sempre resultante de processos nos quais realidade e ficção se conjugam na construção de personagens que acabam sendo nomeados como identidades. Em suma, é possível dizer que toda narrativa é atravessada por uma multidão de biografias ficcionalmente construídas. O pesquisador poderá desprezar tal multidão de vozes para procurar a ipssima vox autoris, ou ouvir nessa multidão a polifonia constitutiva dos sentidos. 


\section{Sem ficção, o que sobra é certeza; sem metáfora, a doutrina torna-se a única alternativa}

A teologia protestante como herdeira da Modernidade - e aqui não importa fazer distinção entre exegese como investigação histórica e teologia como interpretação da experiência da fé - investiu todas as suas energias na formulação de métodos para o alcance da verdade. Não importa se de maneira apologética ou crítica, ela acaba decaindo em fundacionalismo discursivo, à medida que opera um reducionismo do amplo universo religioso ao conceito correto. A reta doutrina (ALVES, 2005) e o historicismo crítico tem certa equivalência: ambas operam o mesmo instrumental racionalista, contudo, de formas distintas.

Tal fixação na execução do método produziu uma teologia, que semelhantemente aos estudos de literatura, nada mais é que história das ideias teológicas. Vivemos, portanto, num império do pensamento conceitual que desqualifica a dimensão ficcional em nome de um realismo que nada mais é do que uma tradição criada e artificialmente envelhecida. Ou seja, o próprio suposto realismo, conquanto se funde na ideia de que o mundo pode ser substancialmente traduzido para a linguagem conceitual, também é uma construção historicamente datada.

Há um conluio de duas forças - que, na verdade, diz respeito a uma mesma força que se mostra de duas formas diferentes - para desqualificar a ficção. Tratase, por um lado, do pensamento dogmático que tem seu fundamento na tradição (aqui é o lugar privilegiado da religião) e, por outro, do racionalismo que se ancora num reducionismo da realidade subtraindo dela sua complexidade (a ciência é o campo onde mais prospera essa matriz). Embora cada uma dessas formas de pensar apareça mais em certa instância da vida, ambas se encontram em dinâmica de intercâmbio permanente.

O império do pensamento conceitual encontra no domínio do dogma e do racionalismo o ambiente próprio e adequado. Dogmatismo e racionalismo não suportam a ficção e fazem isso de forma diferentemente igual (quem adora definir a 
verdade odeia oximoros). O dogmatismo vê no pensamento ficcional, quando aplicado ao seu objetivo (a fé), uma forma de falsear “A” verdade; já o racionalismo (que vive de conceitos e abstrações) expulsa a ficção de seu acervo de métodos capazes de conduzir o pesquisador até “A” verdade.

O que identifica ambos? Alguns diriam: os dois se dedicam ao conhecimento correto (chamamos isso de verdade). É possível, contudo, dizer diferente: não há um interesse na verdade, há, sim, um interesse nesse nefasto artigo definido. Os dois querem “A”. Os dois querem “A” verdade. Querem a segurança de poder dizer a realidade no singular, afinal, a possibilidade da complexidade e contradição os assusta igualmente. Não suportam “e”, querem sempre "ou”. Nas palavras de Cecília Meireles, “isso e aquilo” é preterido em favor do "isso ou aquilo”.

Ou se tem chuva e não se tem sol,
ou se tem sol e não se tem chuva!
Ou se calça a luva e não se põe o anel,
ou se põe o anel e não se calça a luva!
Quem sobe nos ares não fica no chão,
quem fica no chão não sobe nos ares.
E uma grande pena que não se possa
estar ao mesmo tempo nos dois lugares!
Ou guardo o dinheiro e não compro o doce,
ou compro o doce e gasto o dinheiro.
Ou isto ou aquilo: ou isto ou aquilo...
e vivo escolhendo o dia inteiro!
Não sei se brinco, não sei se estudo,
se saio correndo ou fico tranquilo.
Mas não consegui entender ainda
qual é melhor: se é isto ou aquilo.
(MEIRELES, 1990, p. 112)

O dogmático e o racionalista - se cabe aqui uma metáfora! - são marinheiros que amam mais o cais do que o mar. Acabam tomando o cais como lugar de ensinar sobre o mar. Fazem desse lugar seguro o espaço da redução daquilo que os apavora. Dizem: "o mar é bravio", mas não querem experimentar a angústia de não ter chão seguro debaixo de seus pés. Dogmáticos e racionalistas não podem mesmo tolerar a ficção. Esta não se detém às explicações seguras (e igualmente artificiais) que um perito sobre o mar oferece a partir da segurança do cais. A ficção abraça a angústia do mar bravio, do abismo do "sem sentido", da dor insuportável que não cabe em nenhum discurso que comece com “A...”. 
O pensamento ficcional, que o dogma chama de mentira e o racionalismo de entretenimento, assume a densidade mais complexa da realidade e ousa falar sem a intensão de fazer sermões confortadores, nem cartilhas conceituais sobre a natureza das coisas (ROCHA, 2010, p. 198). A ficção tem a petulância de dizer as coisas como são: complexas, contraditórias, sem sentido, insuportáveis. Quem tem o mínimo de sensibilidade para perceber a potência da ficção notará que ela diz a entranha da realidade usando a estratégia da narratividade. Não há credos definitivos, nem leis últimas, há um "era uma vez", um "no princípio", um "e disse uma parábola". Mas, exatamente ali, na esteira do ficcional, aparece a complexidade do real.

O que diz mais sobre a realidade? O modelo de perfeição do dogma, as noções generalistas do discurso racionalista, ou aquela menina de chapéu vermelho que desobedece a mãe para flertar com o lobo? Essa menina não cabe na religião (a não ser como desvio - pecado), não faz sentido para a razão (a não ser como desvio - psicopatologia), mas, não é exatamente ela que melhor expressa nossas complexidades e contradições? E ela expressa melhor, não por apego ao "A" de uma fala perfeita, mas, porque privilegia a coisa tratada assim como aparece, sem mediação nem do "sim" do dogma nem do "não" do conceito.

Felizmente há uma rebelião do objeto que nega seu assujeitamento. E, nesse sentido, é preciso aceitar a crítica de Gumbrecht a uma estética da recepção (o que inclui a ficcionalidade) que se fia apenas na produção de sentido, à revelia da produção de presença, ou seja, à revelia da coisidade estética e substancial dos objetos e sua fruição. Sua crítica nos ajuda a entender que há uma materialidade no mundo que também nos desafia em nossas pretensas apreensões hermenêuticas da realidade (GUMBRECHT, 2010). E, é claro, essa rebeldia do objeto não deve ser lida como a prova de que a realidade independe completamente dos sujeitos e, por isso, deve ser apreendida em sua substancialidade, como diria a Modernidade, o senso comum, as vítimas do saber tácito do mundo, ou mesmo os senhores do "A". Afinal, como já vimos, esse também é um pressuposto que não compreende sua própria relatividade e historicidade. Ao contrário, aceitar essa suposta rebeldia 
equivale a aceitar que a tal realidade é sempre uma construção provisória, afinal, aquilo que um dia apreendemos, pode sempre se rebelar uma vez mais. Na literatura ficcional, por exemplo, isso se dá quando um bicho fala. Todos sabemos que bichos não falam (dizem os senhores do “A”). De onde vem essa certeza? Arrisca-se: da vontade de poder, do querer manter o privilégio da fala. Afinal, quem esse bicho pensa que é pra poder falar? Para além dos interditos dos senhores do “A”, tem-se que é exatamente essa ruptura com o suposto real - lugar de nossa realidade cotidiana - que provoca uma fratura em nossas consolidadas experiências de realidade, capaz de nos tirar da zona de conforto e reconstruir uma vez mais nosso mundo de sentido.

Essa ruptura é significativa quando nos damos conta de que a cotidianidade das pessoas - esse mundo de regras, de costumes, ideologias, divisões de classe, etc. - cria a ilusão de realidade. Ou seja, a permanência nesse mundo no qual somos construídos na medida em que com ele interagimos, faz com que tal cotidianidade seja percebida como sendo constitutiva da realidade. Quando tais percepções são adensadas por ideologias políticas e/ou religiosas, esse senso de realidade tende a se consolidar ainda mais, prestando-se como referencial universal para compreensão do mundo. É nesse momento, por exemplo, que a ficção literária, para além de um simples gênero textual, tem a força de conduzir seus leitores a um mundo que rompe com regras e instituições que até então serviram como referencial de realidade. Quanto a isso, assim se expressa Nogueira, ao comentar a ficcionalidade na perspectiva de Iser:

De repente, um homem ou uma mulher abre uma obra de ficção literária, digamos Crime e Castigo, de Dostoievsky, e se defronta já nas primeiras páginas com a história de um jovem pobre e endividado, Raskolnikov, que trama o assassinato de uma velha agiota. Seus monólogos justificam a ação: quem ficará sabendo? Quanta gente seria favorecida com a morte de sua cruel credora? Não seria ele, Raskolnikov, também favorecido? Já nas primeiras páginas os leitores são mergulhados num mundo de dúvidas, sugestões, tentações, possibilidades de arrependimento, de sucesso, de ser pego, preso, redimido etc. As leis, as divinas e as da sociedade, são questionadas. As convenções são suspensas. Elas são, na perspectiva de W. Iser, "despragmatizadas". A literatura exerce aqui uma sutil, mas poderosa função de desconstrução do real e do estabelecido. (NOGUEIRA, 2015, p. 127-128). 
Há uma arbitrariedade na linguagem em relação ao mundo por ela designado que não pode ser questionado pelas pessoas comprometidas com a cotidianidade do mundo. O texto ficcional, entretanto, é a chance que têm de suspender seu senso de realidade e as certezas que ele supõe e se aliar aos personagens da trama ficcional em ações não sancionadas pelo discurso oficial, numa cumplicidade que subverte as convenções e suas funções reguladoras. Na medida em que essas convenções são verticais, Iser fala de uma horizontalização de relações. Ou seja, o texto ficcional realiza uma seleção de convenções a partir da variedade encontrada no mundo real e as coloca juntas, como se estivessem relacionadas, reorganizando-as horizontalmente em combinações inesperadas capazes de arrefecer a sua validade (ISER, 1975, p. 14).

A ficcionalidade nos lança num lugar onde somos obrigados a aceitar o fato de que certamente há mais coisa entre o céu e a terra do que julga nossa pretensiosa necessidade de dominar o “A”. Não se pode negar que onde se coloniza e se nega a ficção, reina o domínio da fixação.

\section{Dois aportes teológicos para a recuperação do pensamento ficcional como} alternativa ao dogmático/conceitual.

Na tentativa de propor uma aproximação entre teologia e ficcionalidade, busca-se, neste momento, propor dois aportes teológicos, potencialmente capazes de enriquecer uma abordagem teológica que se ancore na recepção, não apenas em seu aspecto hermenêutico, mas, também, na perspectiva da materialidade do mundo e sua fruição.

\subsection{O Deus-para-nós de Joseph Moingt}

O teólogo Joseph Moingt, sobretudo em sua obra Deus que vem ao homem: do luto à revelação de Deus (Moingt, 2010), oferece-nos um caminho interessante e rico a partir do qual é possível se pensar uma aproximação entre teologia e ficcionalidade. O projeto de Moingt já pode ser percebido no título: 
O substantivo o homem designa tanto o indivíduo Jesus em quem Deus se revela aos seres humanos quanto o gênero humano com quem ele vem para fazer história; o verbo vir, por outro lado, indica o tipo de consideração sobre Deus que se adotará: o gênero narrativo mais do que o metafísico; além disso, a consideração narrativa introduz também uma proposição relativa: Deus que vem. (MOINGT apud ROCHA, 2017, p. 991).

Moingt quer pensar Deus enquanto um ser-para-nós. A morte de Deus, longe de ser a expressão ateísta de uma geração que se esqueceu de Deus, pode ser o abandono de uma narrativa que não se adequa à revelação de Deus em Jesus Cristo. Ou seja, em sua perspectiva, deve-se aquiescer ao anúncio da morte de um Deus que não passa de um sonho humano alimentado por suas pretensões de absolutidade, um Deus que fora exilado pelos homens no vazio do céu metafísico. Definitivamente, esse Deus desaparecido não corresponde àquele que se encarnou na história de Jesus. Trata-se, ao contrário, do Deus todo-poderoso, do Totalmente Outro das antigas religiões. Nesse sentido, Moingt se une a outros pensadores, tais como Gianni Vattimo, René Girard, John Caputo e outros - cada um a seu modo e a partir de seu próprio horizonte teórico -, que assumiram a constatação nietzschiana da morte de Deus, vendo nisso a possibilidade de dissolução de um pensamento metafísico, seja este visto na perspectiva da força (Vattimo), da violência (Girard) ou mesmo da clausura linguística (Caputo). 4

Para Moingt, em Jesus, a morte de Deus se desdobra de muitas formas: morre o Deus que intervém na história desde o seu exílio; morre o Deus absoluto, infinito e necessário pressuposto pela filosofia; morre o Deus Onipotente da religião; morre o Deus concebido como objeto do saber e garantia de uma fé que se estrutura a partir do conhecimento objetivo; enfim, morre o Deus da metafísica, alheado do drama humano e deficiente de presença mundana.

A morte de um Deus metafísico, então, possibilita a Moingt propor uma nova narrativa, na qual Deus deixa de ser concebido na perspectiva da necessidade e passa a ser percebido na perspectiva da gratuidade. Moingt sugere que se integre ao ser de Deus sua relação com o mundo, com a história. Introduzir a história no

\footnotetext{
${ }^{4}$ Quanto ao modo como esses autores perceberam o pensamento metafísico e fizeram suas respectivas críticas, ver os seguintes artigos: a) Vattimo e Girard (ROCHA; OLIVEIRA, 2018); Caputo (ROCHA, 2018).
} 
conceito de Deus possibilita que ele seja compreendido a partir das contingências que atravessam o mundo dos humanos; deixa de ser percebido como aquele que é e passa a ser compreendido como aquele que vem. Claramente percebe-se que Moingt deseja sugerir uma revelação que seja concebida na perspectiva da recepção humana. Ou seja, em sua manifestação, Deus é tal como aparece. Portanto, integrase ao em-si de Deus o seu para-nós (MOINGT, 2010, p. 12-14).

Moingt assinala a recepção de Jesus pelos primeiros cristãos judeus como uma crença fundamentada em uma espécie de fé prévia no Deus da Bíblia. Eles creram em Jesus, ancorados numa fé previamente sustentada pela esperança de uma libertação, considerando serem herdeiros de uma história de violências e opressões. Esses cristãos "não podiam receber dele a revelação de Deus caso ela não lhes viesse de mais longe, da tradição de seus pais” (MOINGT, 2010, p. 408). Mas, embora abraçassem Jesus como o Deus de seus pais, o que aponta para certa continuidade, também tiveram que acolher uma dupla ruptura de sua tradição: tanto não conseguiram a restauração do reino que esperavam quanto precisaram abandonar a segurança da lei e as consequentes garantias que ela fornecia.

Os cristãos de origem pagã, por sua vez, foram orientados a identificarem ao Criador da Bíblia o Deus dos deuses soberano, que reconheciam confusamente. “As velhas lendas das genealogias divinas serviam a eles de 'crença disponível' para aderir ao verdadeiro Filho único de Deus, como sabedorias filosóficas ajudavam outrora tê-lo como o Logos pelo qual Deus concebia e organizava o universo” (MOINGT, 2010, p. 408). Ou seja, mesmo os pagãos eram levados a crer a partir de uma continuidade de sua história, tecida por tradições religiosas e filosóficas. Portanto, a revelação de Deus em Jesus chegava aos pagãos, pelo menos em parte, por caminhos já trilhados por seus antepassados. Mas, eles também experimentaram a novidade e a ruptura: a unicidade e universalidade de Deus; a libertação das determinações e da força do destino; o acesso à novidade também se condicionava à ruptura com as solidariedades sociais e éticas, que eram a base dos cultos da cidade e dos seus costumes; o rompimento com os laços sagrados com a natureza, etc. (MOINGt, 2010, p. 408-409). 
Esse duplo movimento, de continuidade e ruptura, aponta para o duplo caráter da ficcionalidade, tal como apontamos anteriormente: por um lado, ver o ser de Deus sob o horizonte da história, da nossa história, necessariamente implica em se considerar que o objeto da fé não se separa da subjetividade da fé; por outro, há uma rebeldia do objeto que nos desarticula e provoca um rompimento com a verticalidade das instituições e convenções que nos dão a sensação de realidade no contexto da cotidianidade.

Abandonar o Deus da metafísica, pois, implica em se abrir mão daquilo que se convencionou chamar de "realidade de Deus" com vistas a uma nova narrativa, uma narrativa ficcional, na qual Deus e ser humano constroem mutuamente a sua própria história que pode se manifestar em narrativas cada vez mais libertadoras. A cultura da morte de Deus desvela a inautenticidade da narrativa metafísica e nos convida a novas narrativas, nas quais ficcionalidade e realidade se perpassam mutuamente e nos convidam uma vez mais a entrarmos nessa trama, que é a história do Deus-que-vem-a-nós.

\subsection{O pluralismo cultural-linguístico de George A. Lindbeck}

George Lindbeck, 5 sobretudo em seu livro The Nature of Doctrine Religion and Theology in a Postliberal Age, estabelece uma importante discussão sobre a linguagem e o lugar que esta ocupa na formulação e comunicação de conteúdos teológicos. A partir da classificação de algumas tipologias, Lindbeck propõe uma abordagem que chamou de teoria cultural-linguística.

Lindbeck aponta para a existência de três teorias teológicas de religião e doutrina (LINDBECK, 1984, p. 30-45): a primeira teoria corresponde a uma teologia pré-liberal ou pré-moderna marcada por um discurso de ordem ontológica que se identifica com a verdade em si. Haveria, portanto, uma continuidade necessária entre a verdade de caráter absoluto e determinado discurso acerca dela. É natural, nessa teoria, a reivindicação da verdade como adequação perfeita entre

\footnotetext{
${ }^{5}$ Lindbeck nasceu em 1936, na China, filho de pais missionários. É professor emérito de Teologia Dogmática e História do Dogma na Divinity School e no Departamento de Estudos Religiosos de Yale, New Haven, Connecticut, EUA.
} 
as ideias e a realidade objetiva. Essa teoria Lindbeck chama de cognotivistaexclusivista.

A segunda teoria corresponde à Teologia Liberal ou moderna. Nela a principal marca é um discurso de ordem simbólica. Nesse caso, a verdade teológica pode ser verificada numa espécie de fundo comum a todas as tradições religiosas. Compreende-se dessa forma que há uma unidade religiosa subjacente a todas as culturas. Dessa maneira, seria possível uma Teologia de caráter inclusivo que se basearia fundamentalmente nos elementos comuns às diversas realidades culturais, uma espécie de essencialismo opaco que torna comum certo fundamento religioso presente nas mais diversas religiões. Nesta abordagem enfoca-se, portanto, a dimensão experiencial-expressiva da religião que interpreta a doutrina como conjunto de símbolos que não são informativos nem discursivos. $O$ fundamental das religiões são os sentimentos interiores de orientação existencial. A experiência é o comum das tradições religiosas.

A teoria proposta por Lindbeck é a cultural-linguística (LINDBECK, 1984, p. 46-72). Enquanto os cognitivo-proposicionalistas entendem a verdade como correspondência ontológica e os experiencial-expressivistas como função de eficácia simbólica, os cultural-linguísticos veem a verdade como gramática ou conjunto de regras do jogo. "Uma doutrina é verdadeira quando ajuda a organizar a vida da pessoa no seu sistema sociocultural” (LINDBECK, 1984, p.57). A teoria cultural-linguística surge como forte crítica das demais tentativas de incursão no universo das tradições religiosas, sobretudo, àquelas gestadas no espírito da Modernidade. Essa teoria, portanto, pode ser chamada de pós-moderna ou, como o autor prefere, pós-liberal.

A condição pós-liberal afirma-se com relação ao liberalismo teológico protestante e a todo o seu ethos. O ser pós-liberal implica, portanto, uma superação das estruturas exegético-teológicas do liberalismo, bem como de toda tentativa de síntese da filosofia que o subjaz, sobretudo da metanarrativa e da suficiência do sujeito cognitivo. Na formulação da teoria cultural-linguística, Lindbeck dialogou com inúmeras influências que sofreu ao longo de sua formação. Três dessas 
influências merecem destaque. Em primeiro lugar, a Teologia Narrativa destaca-se como a grande influência sobre o pensamento de Lindbeck presente na sua teoria cultural-linguística, sobretudo, aquela propugnada pelo teólogo norte americano Hans Frei. A Teologia Narrativa permitiu a Lindbeck um deslocamento no eixo da Teologia Liberal e pré-liberal. Ele aponta para a radical dependência que a teologia deve ter da própria narrativa bíblica. Isso acabou por aproximar sua teologia dos aportes advindos dos estudos literários. Qualquer extratextualidade deve ser substituída pela intratextualidade (LINDBECK, 1984, p.112).

Em segundo lugar, outra importante influência para a teoria culturallinguística é a Filosofia da Linguagem, sobretudo, a do segundo Wittgenistein. Da filosofia da linguagem Lindbeck absorve a crítica ao essencialismo linguístico, ou como diz Wittgenstein, o uso metafísico da linguagem:

Quando os filósofos usam uma palavra - saber, ser, objeto, eu, proposição, nome - e procuram apreender a essência da coisa, deve-se sempre perguntar: essa palavra é usada de fato desse modo na língua em que ela existe? Nós reconduzimos as palavras do seu emprego metafísico para seu emprego cotidiano. (WITTGENSTEIN, 1992, p. 66).

Nesse sentido muda-se de uma teoria onde a palavra representa uma realidade para outra em que a palavra propõe a realidade. "O significado de uma palavra é o seu na linguagem" (LINDBECK, 1984, p. 58). Na variedade do uso da palavra já está, portanto, a variedade da realidade e, por isso, o uso comum (ou metafísico-essencialista) da linguagem é descartado: "Em vez de indicar algo que é comum a tudo aquilo que chamamos linguagem, digo que não há coisa comum nesses fenômenos" (LINDBECK, 1984, p.62).

Em terceiro lugar, há ainda outro elemento que marcou profundamente a teoria cultural-linguística: a Antropologia Cultural, sobretudo em Clifford Geertz. Dela Lindbeck toma a radical crítica a universalismos que ocorrem em detrimento das particularidades culturais. Geertz observa certa "noção de consensus gentium... onde há coisas que todos os homens concordam como corretas, reais, justas ou atrativas, e que de fato essas coisas são, portanto, corretas, reais, justas ou atrativas” (GEERTZ, 2013, p. 29). Essa ideia de consensus gentium (consenso de 
toda a humanidade) será fortemente atacada por Geertz no âmbito de sua antropologia:

A busca de universais afasta-nos do que se revelou genuinamente produtivo [...] e nos leva para uma abrangência rala, implausível e predominantemente pouco instrutiva. Se você quiser uma boa generalização sugiro a seguinte: qualquer frase que comece por "Todas as sociedades têm...” é infundada e banal. (GEERTZ, 2013, p. 29).

Tratando ainda da tendência de ler o outro a partir das categorias de determinada sociedade, ele diz:

Em vez de tentar encaixar a experiência das outras culturas dentro da moldura desta nossa concepção, que é o que a tão elogiada "empatia" acaba fazendo, para entender as concepções alheias é necessário que deixemos de lado nossa concepção, e busquemos ver as experiências de outros com relação à sua própria concepção do "eu". (GEERTZ, 1997, p. 91).

A partir dessas influências, Lindbeck desenvolve sua teoria para analisar como o cristianismo se autocompreende e se comunica. Para a teoria culturallinguística a questão não está na garantia de verdades proposicionais, simbólicas ou práticas. Antes, a questão é de qual discurso adapta melhor suas categorias à realidade. Na esteira das influências da filosofia da linguagem e da antropologia cultural, a teoria cultural-linguística diz que afirmações doutrinárias são verdades intra-sistêmicas (LINDBECK, 1984, p. 64), nesse sentido, só é possível entender uma sentença teológica a partir de seu próprio contexto. A teoria culturallinguística é pluralista, mas, essa sua condição se estabelece numa dinâmica que se dá a partir de baixo e não a partir de cima, ou seja, ela busca seus fundamentos na diversidade cultural e não na divindade.

O pluralismo linguístico abre-se à compreensão da condição hermenêutica da teologia, por um lado, e dos diversos horizontes de sentido, por outro. Um saber hermenêutico precisará se fazer e refazer em cada horizonte de compreensão a partir do qual ele se ocupa do tema da verdade. Exatamente aqui o tema da ficção encontra uma cunha. A ficção é, portanto, a possibilidade de dizer o possível sobre tais realidades locais que precisam ser construídas e reconstruídas na dinâmica histórica. Buscando superar um exclusivismo onde um particular é universalizado, 
e um inclusivismo onde os particulares são neutralizados em nome de uma base experiencial comum, Lindbeck insere-se no pluralismo (diferenciando-se das tentativas de encontrar na divindade os seus motivos), no sentido de perceber e valorizar o particular como locus da teologia.

\section{Conclusão}

Para além das perspectivas modernas, do senso comum ou mesmo do saber tácito, o presente artigo procurou reafirmar a tradição que procura reler o papel da ficcionalidade em sua relação com aquilo que a tradição ocidental convencionou chamar de realidade. Mais do que isso, procurou-se tratar a relação ficçãorealidade no contexto da formulação de discursos teológicos. Diante da crítica aqui esboçada, é inevitável que se perceba que, enquanto construção historicamente datada, a realidade também é eivada de ficcionalidade. Em qualquer raciocínio não se pode esquivar-se dos pressupostos e, sejam eles verdadeiros ou não, há um grau de ficcionalidade que lhes é inerente. Mesmo o discurso científico - que se assenta primariamente sobre hipóteses, sobre pressupostos - não pode esgueirar-se do ficcional.

Nos termos da discussão aqui sugerida, é inevitável que se aquiesça às intuições oriundas da chamada Estética da Recepção, sobretudo as que dão origem às reflexões de Wolfgang Iser, para quem os limites entre realidade e ficção não são muito claros, afinal, toda ficção traz uma carga de realidade e toda realidade também é eivada de ficcionalidade. Para a compreensão da obra - vista aqui numa perspectiva ampla -, é preciso jogar o jogo de faz-de-conta proposto pelo autor/texto aos seus leitores. É necessário aceitar esse nível diferenciado de verdade para se entender a narrativa ficcional. Nesse sentido, há uma transformação dos sentimentos do leitor da ficção em sentimentos de segundo grau, que são amparados na verdade da ficção, e que suscita respostas reais de nossa parte. Se nossa perspectiva a respeito do mundo é conscientemente a de receptor, então o que interessa, de fato, é a resposta do leitor e nem tanto em que medida a obra se estrutura ou em que medida se dá a relação entre realidade e 
ficção na obra - acreditamos que os aportes sugeridos a partir de Moingt e Lindbeck possibilitam esse olhar. Deve-se ressaltar, ainda, que essa resposta nem sempre se dará no nível hermenêutico, mas, também, no nível estético.

Entretanto, apesar de possibilitar uma interessante base teórica para se repensar a Teologia, essa tradição que prioriza a recepção e os receptores também precisa ser atualizada, repensada, o que significa que não está imune à crítica. A discussão pode e deve ser problematizada para que possibilite aportes teológicos cada vez melhores. Uma das questões presentes nas formulações de Iser que mereceriam maior atenção, e que não está no escopo deste artigo, tem a ver, por exemplo, com a emergência de vazios no texto que mostram como pontos de indeterminação tornam a recepção algo confuso e incontrolável. Para Iser, essas indeterminações devem ser "normalizadas", ou seja, devem ser domesticadas e sujeitadas a uma estrutura de sentido estável, o que significa uma redução do potencial polissêmico a alguma ordem. Quanto a isso é preciso perguntar se as indeterminações do texto, no final das contas, não é um estímulo a aboli-las, substituindo-as por um significado sempre mais estável. Merece nossa atenção e investigação, por exemplo, movimentos que lidam de forma mais plástica com o texto, tais como o pentecostalismo, mas que mesmo assim acabam se dirigindo a essa "normalização" que descamba para algo muito próximo ao dogma (mesmo que este seja tácito). Também não estaríamos diante de um paradoxo antropológico? Ou seja, assim como é inerente à condição humana a criação de representações também parece ser a busca por estabilidade, por uma "normalização". Que essas inquietações inspirem novas reflexões que elucidem cada vez mais a relação entre realidade e ficção e seus desdobramentos com vistas à formulação de discursos teológicos.

\section{REFERÊNCIAS}

ALVES, Rubem. Religião e repressão. São Paulo: Loyola, 2005.

ASSMAN, A. Die legitimität der fiktion: ein Beitrag zur Geschichte der literarischen kommunication. Munique: Wilhelm Fink Verlag, 1980. 
BACON, Francis. Vida e obra. São Paulo: Editora Nova Cultural, 1999.

GEERTZ, Cliford. O saber local: novos ensaios em antropologia interpretativa. Petrópolis: Vozes, 1997.

GEERTZ, Cliford. A interpretação das culturas. São Paulo: LTC, 2013.

GUMBRECHT, Hans Ulrich. Produção de presença: o que o sentido não consegue transmitir. Rio de Janeiro: Contraponto: Editora PUC-RIO, 2010.

HABERMAS, J. El discurso filosófico de la modernidad. Madri: Taurus, 1989.

ISER, Wolfgang. The reality of fiction: a functionalist approach to literature. New Literary History, Baltimore, Maryland, v. 7, n. 1, p. 7-38, 1975.

ISER, Wolfgang. O fictício e o imaginário: perspectivas de uma antropologia literária. Rio de Janeiro: EDUERJ, 1996.

JAUSS, Hans Robert. A história da literatura como provocação à teoria literária. São Paulo: Ática, 1994.

LINDBECK, George. The nature of doctrine religion and theology in a postliberal age. Philadelphia: Westminster Press, 1984.

KANT, I. A paz perpétua e outros opúsculos. Lisboa: Edições 70, 2004.

MEIRELES, Cecília. Ou isto ou aquilo. São Paulo: Editora Nova Fronteira, 1990, p. 112.

MOINGT, Joseph. Deus que vem ao homem: do luto à revelação de Deus. São Paulo: Loyola, 2010.

NOGUEIRA, Paulo Augusto de Souza. Religião e ficcionalidade: modos de as linguagens religiosas versarem sobre o mundo. In: NOGUEIRA, Paulo Augusto de Souza (Org.).

Religião e linguagem: abordagens teóricas interdisciplinares. São Paulo: Paulus, 2015.

ROCHA, Abdruschin Schaeffer. Entre o dizer e o não dizer: por uma epistemologia da revelação nos limites da linguagem. Teoliterária, São Paulo, v. 8, n. 15, p. 92-121, 2018.

ROCHA, Abdruschin Schaeffer. O Deus que vem a nós: reflexões hermenêutico-teológicas da revelação desde cima e desde baixo. Horizonte, Belo Horizonte, v. 15, n. 47, p. 974996, jul./set. 2017.

ROCHA, Abdruschin Schaeffer; OLIVEIRA, David Mesquiati de. Teologia da missão e violência: superar a violência interna e agir energicamente contra a injustiça. Revista Pistis \& Praxis: Teologia e Pastoral, Curitiba, v. 10, n. 1, p. 144-166, jan./abr. 2018.

ROCHA, Alessandro Rodrigues. Experiência e discernimento. Recepção da palavra numa cultura pós-moderna. São Paulo: Fonte Editorial, 2010.

WITTGENSTEIN, L. Investigações filosóficas. São Paulo: Ed. Abril Cultural, 1992. 